ISSN : $2302-1590$

E-ISSN: $2460-190 \mathrm{X}$

ECONOMICA

Journal of Economic and Economic Education Vol.4 No.1 (11-18)

\title{
IMPLEMENTASI MODEL PEMBELAJARAN ARIAS DALAM UPAYA MENINGKATKAN PARTISIPASI DAN HASIL BELAJAR EKONOMI SISWA KELAS VIII PADA SMP N 10 PADANG
}

\author{
Nilmadesri Rosya \\ Dosen Program Studi Pendidikan Ekonomi STKIP- PGRI Sumbar \\ Jl. Gunung Pangilun No.1, Padang Sumatera Barat \\ Email : nilmadesrirosya@yahoo.co.id
}

Submitted: 2015-10-15 Reviewed: 2016-04-14 Accepted: 2016-06-20

http://dx.doi.org/10.22202/economica.2015.v4.i1.309

\begin{abstract}
This study aims to see increased participation and student learning outcomes by using model study on subjects ARIAS Economy class VIII.3 in SMP N 10 Padang. This research is a classroom action research with the hypothesis of action is the application of learning models ARIAS can increase participation and learning outcomes Economy class students VIII.3 SMP N 10 Padang. Data were collected through observation sheet that is used to view changes in participation and learning outcomes of students in the learning process cycle I and II. The results of the two cycles shows that participation and learning outcomes of students has increased since the first cycle and this improvement continued in the second cycle
\end{abstract}

\begin{abstract}
Abstrak
Penelitian ini bertujuan untuk melihat peningkatan partisipasi dan hasil belajar siswa dengan menggunakan model pembelajaran ARIAS pada mata pelajaran Ekonomi kelas VIII.3 di SMP N 10 Padang. Penelitian ini merupakan Penelitian Tindakan Kelas dengan hipotesis tindakannya adalah penerapan model pembelajaran ARIAS dapat meningkatkan partisipasi dan hasil belajar Ekonomi siswa kelas VIII.3 SMP N 10 Padang. Data dikumpulkan melalui lembaran observasi yang digunakan untuk melihat perubahan partisipasi dan hasil belajar siswa dalam proses pembelajaran siklus I dan II. Hasil penelitian dari dua siklus menunjukan bahwa partisipasi dan hasil belajar siswa mengalami peningkatan sejak siklus I dan peningkatan ini berlanjut pada siklus II.
\end{abstract}

Keywords: ARIAS Learning Model, Participation and Learning Outcomes 


\section{PENDAHULUAN}

Untuk mewujudkan manusia Indonesia yang berkualitas banyak kendala yang ditemui, salah satu diantaranya rendahnya mutu pendidikan yang disebabkan oleh berbagai faktor. Faktor yang terpenting adalah guru, karena guru mempunyai peranan yang sangat besar dalam mewujudkan kelancaran proses pembelajaran baik sebagai fasilitator, motivator, komunikator sehingga proses pembelajaran berjalan sebagaimana mestinya.

Berdasarkan pengamatan awal penulis di SMP N 10 Padang didapati bahwa proses pembelajaran terpusat pada guru (teacher centered) dimana guru dianggap gudang ilmu sebagai satu-satunya sumber informasi dan mendominasi kegiatan belajar. Proses pembelajaran berlangsung mekanistik yaitu guru menjelaskan materi dan siswa mendengarkan dan ada juga yang mencatat. Bahkan ada guru yang tidak mejelaskan materi pelajaran, namun hanya membacakan materi pelajaran agar dicatat oleh siswa tanpa memberikan penjelasan dan contoh terhadap materi yang dibacakannya.

Pembelajaran yang demikian membuat siswa bosan dan tidak berpartisipasi dalam belajar. Wujud dari kebosanan siswa terlihat selama proses pembelajaran di kelas, ketika guru menerangkan pelajaran siswa banyak yang tidak memperhatikan, mereka sibuk dengan kegiatannya masing-masing, ada yang main handphone, ada yang minta izin keluar dan ketika diberi kesempatan mencatat pelajaran banyak dari siswa yang tidak mencatat, kalaupun ada yang mengerjakannya itupun sambil bercerita dengan teman sebangku. Begitu juga kalau diberi kesempatan oleh guru untuk bertanya, siswa hanya diam kalaupun ada yang bertanya hanya satu atau dua orang dengan siswa yang sama dari minggu ke minggu. Dalam mengerjakan latihan yang diberikan guru, siswa banyak yang mencontek kepada temannya yang pintar tanpa berusaha sendiri mencari jawabannya atau bertanya kepada guru tentang kesulitan yang mereka hadapi dalam mengerjakan latihan tersebut.

Karena kondisi proses pembelajaran siswa yang seperti itu tentulah berpengaruh terhadap hasil belajar siswa. Relatif rendahnya nilai ulangan harian dari siswa SMP N 10 Padang dalam mata pelajaran ekonomi, kemungkinan besar disebabkan oleh masih rendahnya partisipasi belajar siswa dalam belajar sehingga berdampak terhadap hasil belajar yang rendah pula pada mata pelajaran ekonomi.

Untuk meningkatkan hasil belajar siswa yang rendah di atas, guru harus mampu menciptakan suasana yang menarik dalam proses pembelajaran, sehingga bisa merangsang siswa untuk bersemangat dan berpartisipasi dalam belajar. Salah satu usaha yang dapat dilakukan guru adalah dengan menggunakan model pembelajaran yang tepat sesuai dengan materinya sehingga menunjang terciptanya kegiatan pembelajaran yang kondusif dan menarik bagi siswa sehingga dapat memperoleh hasil belajar seoptimal mungkin.

Salah satu model yang dapat dikembangkan untuk meningkatkan hasil belajar siswa dalam pembelajaran ekonomi adalah dengan menggunakan model ARIAS, model pembelajaran ini dikembangkan oleh Keller dan Kopp dalam Sopah (2007:7) sebagai jawaban pertanyaan bagaimana merancang pembelajaran yang mempengaruhi hasil belajar. Dalam hal ini guru harus berusaha menciptakan kondisi yang memungkinkan siswa terlibat dan ikut mengambil bagian dalam belajar. Semakin besar keterkaitan siswa dalam proses pembelajaran maka semakin besar kepercayaan diri siswa untuk berpartisipasi aktif dalam belajar.

Di dalam pembelajaran ARIAS ada lima kategori yang harus diperhatikan oleh guru dalam usaha menghasilkan pembelajaran yang menarik, bermakna dan memberikan tantangan bagi siswa. Kelima kategori itu adalah (1) assurance (percaya diri), (2) relevance (relevansi), (3) interest (minat), (4) assessment (evaluasi), dan (5) satisfaction (kepuasan/bangga).

Pada komponen assurance, siswa diberikan tugas mandiri atau pertanyaan dari yang mudah berangsur sampai yang sukar sehingga siswa menjadi yakin, penuh percaya 
diri dan merasa mampu untuk mengerjakan dan menjawabnya.

Pada komponen relevance, diciptakan kegiatan yang mengakibatkan siswa merasa kegiatan pembelajaran yang mereka ikuti memiliki nilai, manfaat dan berguna bagi kehidupan mereka.

Pada komponen interest, diusahakan selalu menjaga minat dan perhatian siswa disetiap pembelajaran. Misalkan pada pertemuan pertama menggunakan media chart dan pertemuan kedua menyediakan alat dan bahan yang sesuai dengan materi, dengan adanya variasi tersebut minat dan perhatian siswa menjadi terpelihara selama proses pembelajaran berlangsung.

Pada komponen assesment, diadakan evaluasi dan memberikan umpan balik bagi siswa, seperti mengumumkan nilai tugas dan nilai latihan setelah diperiksa. Pada proses pembelajaran siswa yang berhasil diberikan penguatan baik secara verbal maupun non verbal.

Pada komponen satisfaction, siswa merasa puas karena tugas mereka diperiksa dan dipresentasikan sehingga dapat diketahui dimana letak kesalahannya. Ini merupakan suatu bentuk evaluasi diri yang membuat mereka bangga dengan apa yang mereka kerjakan dan termotivasi terus untuk mendapatkan hasil yang optimal.

Dengan adanya model pembelajaran ARIAS cenderung menimbulkan kesadaran dalam diri siswa tentang keberadaan dan kegunaan ilmu ekonomi dalam kehidupan manusia, sehingga siswa termotivasi untuk mempelajari ekonomi dengan sungguhsungguh.

\section{METODE PENELITIAN}

Jenis penelitian ini adalah Penelitian Tindakan Kelas. Menurut Arikunto (2008:3) Penelitian Tindakan Kelas merupakan suatu pencermatan terhadap kegiatan belajar berupa tindakan, yang sengaja dimunculkan dan terjadi dalam sebuah kelas secara bersamaan. Penelitian ini dilakukan pada SMP N 10 Padang dengan subjek penelitian adalah siswa kelas VIII.3 yang berjumlah 37 orang siswa yang terdiri dari 19 siswa laki-laki dan 18 siswa perempuan.
Dalam hal ini target penelitian adalah terjadinya peningkatan pembelajaran ekonomi dengan menggunakan model ARIAS. Peningkatan pembelajaran disini mencakup peningkatan partisipasi siswa dan hasil belajar siswa.

Prosedur penelitian yang akan dilakukan yaitu :

\section{Siklus I}

1. Perencanaan

Hal yang dapat diungkapkan disini adalah semua rencana kegiatan yang dilakukan dalam proses pembelajaran, yaitu:

a. Menentukan standar kompetensi yang akan diajarkan

b. Menyusun perangkat (program semester, rincian minggu efektif, silabus dan rencana pelaksanaan pembelajaran)

c. Menyiapkan lembaran observasi

d. Menyiapkan sumber belajar yang harus sesuai dengan materi pembelajaran.

2. Pelaksanaan

a. Apersepsi terhadap siswa dan guru mengabsen siswa

b. Guru bertanya kepada siswa tentang materi pelajaran mulai dari hal yang mudah ke hal yang sulit, dan sebelum siswa menjawab guru memberi penguatan kepada siswa bahwa siswa mampu menjawab tanpa melihat buku. (assurance)

c. Guru menghubungkan materi pelajaran dengan keadaan rill di lapangan dan menjelaskan manfaat dari mempelajari materi tersebut. (relevance)

d. Guru menjelaskan sesuatu hal yang baru yang berhubungan dengan materi pelajaran yang belum diketahui siswa dan membuat penjelasan tersebut menjadi hal yang aneh. (interest)

e. Memberikan tes kepada siswa untuk menilai kinerja siswa tentang materi yang telah dijelaskan. (assesment) 
f. Memberikan penguatan kepada siswa yang mendapat nilai baik secara penguatan verbal. (satisfaction)

3. Pengamatan

Pengamatan terhadap partsipasi siswa dilakukan bersamaan dengan tindakan berlangsung. Pengamatan dilakukan oleh teman sejawat. Pengamatan dilakukan dengan menggunakan lembar observasi.

4. Refleksi

Refleksi yang dilakukan pada siklus I adalah melakukan analisis terhadap hasil tindakan yang telah dilakukan dengan menggunakan lembar observasi yang berisi indikator partisipasi siswa selama proses pembelajaran. Hasil refleksi pada siklus pertama ini akan digunakan sebagai masukan untuk melaksanakan siklus kedua.

\section{Siklus II}

\section{Perencanaan}

a. Menentukan standar kompetensi yang akan diajarkan

b. Menyusun perangkat (program semester, rincian minggu efektif, silabus dan rencana pelaksanaan pembelajaran)

c. Menyiapkan lembaran observasi

d. Menyiapkan sumber belajar yang harus sesuai dengan materi pembelajaran

2. Pelaksanaan

a. Apersepsi terhadap siswa dan guru mengabsen siswa

b. Guru bertanya kepada siswa tentang materi pelajaran mulai dari hal yang mudah ke hal yang sulit, dan sebelum siswa menjawab guru memberi penguatan kepada siswa bahwa siswa mampu menjawab tanpa melihat buku. (assurance)

c. Guru menghubungkan materi pelajaran dengan keadaan riil di lapangan dan menjelaskan manfaat dari mempelajari materi tersebut. (relevance)

d. Guru menjelaskan sesuatu hal yang baru yang berhubungan dengan materi pelajaran yang belum diketahui siswa dan membuat penjelasan tersebut menjadi hal yang aneh. (interest)

e. Memberikan tes atau tugas kepada siswa untuk menilai kinerja siswa tentang materi yang telah dijelaskan. (assesment)

f. Memberikan penguatan kepada siswa yang mendapat nilai baik secara penguatan verbal. (satisfaction)

3. Pengamatan

Pengamatan terhadap partisipasi siswa dilakukan bersamaan dengan tindakan berlangsung. Pengamatan dilakukan oleh observer dengan menggunakan lembaran observasi.

4. Refleksi

Refleksi yang dilakukan pada siklus kedua adalah melakukan analisis terhadap lembar observasi yang berisi partisipasi siswa selama proses pembelajaran berlangsung. Pada siklus kedua ini dapat dilihat perubahan yang terjadi pada partisipasi belajar siswa jika dibanding dengan siklus pertama yang selanjutnya dapat diambil kesimpulan.

\section{PEMBAHASAN}

Hasil penelitian pada siklus I dan II ditemukan bahwa dengan penggunaan model pembelajaran ARIAS pada pelajaran Ekonomi yang diterapkan pada siswa kelas VIII.3 SMP N 10 Padang menyebabkan partisipasi positif siswa yang relevan dengan kegiatan pembelajaran meningkat. Partisipasi siswa yang relevan dengan pembelajaran pada penelitian ini, yaitu memperhatikan penjelasan guru, siswa yang bertanya, siswa yang menjawab pertanyaan, siswa yang mencatat materi, dan siswa mengerjakan latihan.

Sebaliknya, partisipasi siswa yang negatif dan kurang relevan pada saat proses pembelajaran berlangsung mengalami penurunan. Adapun partisipasi yang kurang relevan dengan pembelajaran, yaitu izin keluar kelas, mengganggu siswa lain, siswa 
yang tidak menyelesaikan latihan, siswa yang acuh dalam pembelajaran.

Pada siklus I rata-rata partisipasi positif yang relevan dengan pembelajaran sebesar $51,40 \%$ dan pada siklus II meningkat menjadi $87,02 \%$. Sedangkan partisipasi negatif yang kurang relevan dengan kegiatan pembelajaran pada siklus II mengalami penurunan yaitu 4,96\% sedangkan pada siklus I sebesar 18,41\%. Hal ini sesuai dengan indikator keberhasilan yang diharapkan, yaitu persentase partisipasi positif yang sesuai dengan partisipasi siswa yang relevan dengan pembelajaran $>75 \%$ dan partisipasi negatif $\leq$ $25 \%$.

Pada siklus I partisipasi positif yang mengalami peningkatan paling tinggi yaitu partisipasi dalam mengemukakan pertanyaan sebebesar $27,78 \%$ dan yang mengalami peningkatan paling sedikit adalah partisipasi memperhatikan penjelasan guru, yang pada pertemuan II siklus I hanya meningkat 3 orang siswa yang melakukannya, partisipasi yang paling banyak dilakukan pada siklus I secara rata-rata adalah mencatat materi/halhal penting yang diperoleh dari penjelasan guru yaitu sebesar 63,89\% sedangkan partisipasi yang paling sedikit dilakukan oleh siswa adalah partisipasi dalam menjawab pertanyaan yang rata-ratanya hanya sebesar 29, $17 \%$.

Peningkatan partisipasi siswa dalam pembelajaran dikarenakan materi pelajaran yang disampaikan merupakan materi yang sering ditemui siswa dalam kehidupan seharihari, sehingga guru berusaha memberikan contoh yang relevan dengan kehidupan siswa sehingga banyak hal yang sering mereka pertanyakan terhadap yang mereka temui dilapangan.

Sedangkan partisipasi siswa yang
sedikit mengalami peningkatan yaitu partisipasi siswa dalam memperhatikan penjelasan guru, karena kebanyakan dari siswa yang tidak memperhatikan penjelasan guru sibuk dengan kegiatannya masingmasing salah satunya adalah mengerjakan tugas mata pelajaran lain. Siswa yang tidak memperhatikan penjelsan guru ini tidak meribut, jadi peneliti menganggap mereka serius dalam mengikuti pelajaran, akan tetapi observer mengamati mereka mengerjakan tugas mata pelajaran lain.

Partisipasi positif yang paling tinggi peningkatannya dilakukan oleh siswa pada siklus II adalah partisipasi siswa dalam menjawab pertanyaan yaitu meningkat sebesar 26,03\%. Sedangkan partisipasi yang peningkatannya paling kecil ada 3 partisipasi, pertama partisipasi dalam memperhatikan penjelasan guru karena pada pertemuan I siklus II yang berpartisipasi berjumlah 33 orang siswa dan pada pertemuan 2 siklus II yang berpartisipasi juga berjumlah 33 orang, kedua partisipasi dalam mengemukakan pertanyaan karena pada pertemuan I siklus II yang berpartisipasi berjumlah 27 orang dan pada pertemuan II siklus II juga berjumlah 27 orang, ketiga partisipasi dalam mengerjakan lathan, karena pada pertemuan I siklus II yang berpartisipasi berjumlah 34 orang dan pada pertemuan II juga berjumlah 34 orang. Namun karena jumlah siswa yang hadir pada pertemuan 1 siklus II hanya 35 orang sedangkan pertemuan 2 berjumlah 36 orang maka persentase pada pertemuan 1 siklus II lebih besar dari pertemuan 2. Partisipasi yang paling banyak dilakukan oleh siswa pada siklus II secara rata-rata adalah partisipasi dalam mengerjakan latihan atau sebesar 95,79\%, sedangkan partisipasi yang paling sedikit yang dilakukan oleh siswa pada siklus II adalah partisipasi dalam menjawab pertanyaan yaitu hanya sebesar $75,88 \%$.

Pada siklus I partisipasi negatif yang penurunannya paling tinggi yaitu partisipasi siswa yang acuh dalam pembelajaran yaitu sebesar 8,33\%. Partisipasi negatif yang penurunannya paling rendah terjadi pada partisipasi minta izin keluar kelas dan partisipasi menggangu siswa lain. Untuk partisipasi siswa izin keluar kelas tetap berjumlah 5 orang dan partisipasi siswa mengganggu temannya tetap berjumlah 4 orang. Partisipasi negatif yang paling banyak dilakukan oleh siswa secara rata-rata pada siklus I adalah siswa yang acuh dalam pembelajaran yaitu sebesar 31,95\%. Partisipasi negatif yang paling sedikit dilakukan oleh siswa adalah siswa yang mengganggu siswa lain dengan persentase sebesar $11,11 \%$. 
Penurunan jumlah siswa yang acuh dalam pembelajaran disebabkan karena guru berupaya melibatkan siswa yang terbiasa acuh dalam pembelajaran, seperti memakai nama siswa tersebut dalam contoh yang diberikan guru, dan upaya guru untuk selalu memotivasi siswa selama proses pembelajaran berlangsung.

Pada siklus II penurunan partisipasi negatif yang paling tinggi dilakukan oleh siswa adalah siswa yang acuh dalam pembelajaran sebesar $5,87 \%$. Jadi dapat disimpulkan bahwa pada siklus II perhatian siswa terhadap pembelajaran semakin meningkat. Sedangkan partisipasi negatif yang penurunannya paling rendah yaitu siswa yang tidak menyelesaikan latihan. Partisipasi negatif secara rata-rata yang paling banyak dilakukan oleh siswa adalah partisipasi siswa yang acuh dalam pembelajaran yaitu sebesar $8,50 \%$. Sedangkan partisipasi negatif yang paling sedikit dilakukan oleh siswa adalah siswa yang tidak menyelesaikan latihan, yaitu sebesar 0, artinya tidak ada diantara siswa yang tidak menyelesaikan latihan yang diberikan.

Untuk menurunkan jumlah partisipasi negatif yang dilakukan oleh siswa, guru lebih cenderung menggunakan teguran, pendekatan personal atau ajakan, daripada hukuman. Dalam proses pembelajaran guru juga lebih sering mempercepat pemberian pujian kepada siswa yang terlihat melakukan perubahan ke arah yang positif (mengurangi partisipasi negatifnya), dibandingkan memberikan penilaian atau judgment kepada perilaku negatif siswa.

Pada siklus I nilai harian ulangan siswa dengan rata-rata 61,46 dengan tingkat ketuntasan 15 siswa dengan persentase $41,67 \%$ dan standar deviasinya sebesar 11,82 , sedangkan dari tabel 14 dapat diketahui bahwa pada siklus II rata-rata siswa meningkat menjadi 78,13 dengan ketuntasan 29 siswa dengan persentase $80,56 \%$ dan standar deviasinya 13,67. Hal ini terjadi seiring dengan peningkatan partisipasi positif siswa yang relevan dengan pembelajaran dan penurunan partisipasi negatif siswa yang kurang relevan dengan pembelajaran.
Secara keseluruhan dapat dikatakan bahwa partisipasi dan hasil belajar siswa telah mencapai indikator keberhasilan yang diharapkan yaitu partisipasi positif dalam pproses pembelajaran harus mencapai $>75 \%$ dan partisipasi negatif $\leq 25 \%$, .Sedangkan untuk rata-rata nilai dan ketuntasan klasikal harus mencapai $75 \%$, Namun masih banyak kendala yang perlu diperhatikan guru dalam penggunaan model pembelajaran ARIAS yaitu kemampuan guru dalam mengelola kelas dan kecakapan guru dalam menghubungkan materi pelajaran dengan keadaan dilapangan serta kemampuan menciptakan ketertarikan siswa terhadap materi yang disampaikan serta guru harus bisa menggunakan waktu seefektif dan seefisien mungkin karena model pembelajaran ini membutuhkan banyak contoh dan melibatkan siswa dengan guru. Oleh karena itu, seorang guru harus cepat tanggap terhadap kondisi siswa, dapat membagi perhatian dengan baik ketika mengajar, serta memberikan reaksi terhadap gangguan dalam belajar.

Bagi seorang guru yang profesional sangat dituntut kemampuannya dalam memilih model pembelajaran yang tepat dengan materi yang akan disampaikan, karena berbeda materi berbeda pula model dan strategi pembelajaran yang harus digunakan karena model pembelajaran yang digunakan oleh seorang guru akan berpengaruh terhadap kualitas dan hasil dari proses belajar. Penggunaan model pembelajaran ARIAS mampu meningkatkan partisipasi belajar siswa yang akhirnya dapat meningkatkan hasil belajar siswa.

Untuk menerapkan model pembelajaran ini ada beberapa keadaan yang harus dipenuhi yaitu, model ARIAS ini cocok untuk materi pembelajaran yang cukup dekat dengan siswa dan banyak ditemui siswa dilapangan sehingga guru benar-benar bisa meyakinkan siswa akan manfaat dari mempelajari materi ini. Hendaknya di dalam kelas tersebut tersedia berbagai media yang memadai sehingga guru bisa memvariasikan media agar pembelajaran lebih menarik. Model ni membutuhkan guru yang mampu menjadi motivator bagi setiap siswanya, karena setiap stimulus yang diberikan guru 
akan berpengaruh dalam keberhasilan model ini.

Model pembelajaran ini juga memiliki kekurangan, yaitu model ARIAS ini banyak membutuhkan waktu dalam memberikan contoh kepada siswa, karena dengan memberikan contoh merupakan salah satu cara menarik minat siswa. Materi ekonomi yang bisa disampaikan dengan menggunakan model pembelajaran ARIAS ini terbatas. Dalam melaksanakan kelima komponen dalam pembelajaran ARIAS tidak bisa ditentukan durasi waktu yang jelas untuk setiap komponen tersebut sehingga terkadang peneliti banyak menghabiskan waktu untuk satu komponen sehingga komponen yang lainnya memdapatkan jatah waktu yang sedikit.

\section{PENUTUP}

Berdasarkan hasil penelitian dan pembahasan pada BAB IV terhadap penerapan model pembelajaran ARIAS pada mata pelajaran ekonomi kelas VIII.3 SMP N 10 Padang dengan kompetensi dasar mendeskripsikan Fungsi Pajak dalam Perekonomian Nasional dapat disimpulkan bahwa: 1) Penggunaan model pembelajaran ARIAS dapat meningkatkan partisipasi positif siswa dalam belajar pada mata pelajaran ekonomi. 2) Dengan meningkatnya partisipasi positif siswa dalam belajar pada mata pelajaran ekonomi, maka penerapan model pembelajaran ARIAS juga dapat meningkatkan hasil belajar siswa kelas VIII.3 SMP N 10 Padang pada mata pelajaran ekonomi.

Peningkatan ini tercapai karena penggunaan model pembelajaran ARIAS, proses pembelajaran dimulai dengan memberikan mereka keyakinan akan kemampuan bahwa siswa akan berhasil dalam materi yang akan disampaikan, kemudian selama proses pembelajaran berlangsung guru berusaha membuat materi pelajaran menjadi menarik dan pada akhir proses pembelajaran guru memberikan asessment terhadap siswa dan dari hasil assessment akan diberikan penguatan kepada siswa.
Berdasarkan pengalaman penulis selama melaksanakan penelitian dan hasil penelitian yang diperoleh, maka penulis menyarankan: 1) Kepada pihak sekolah untuk mensosialisasikan model pembelajaran ARIAS, agar dapat digunakan oleh guru dalam pembelajaran karena dapat meningkatkan keyakinan dan ketertarikan siswa terhadap materi. Penggunaan model ini dapat memberikan pengaruh positif terhadap peningkatan partisipasi dan hasil belajar siswa dalam proses pembelajaran Ekonomi. 2) Bagi tenaga pendidik, khususnya guru mata pelajaran Ekonomi diharapkan dapat menerapkan model ini sebagai salah satu alternatif dalam peningkatan partisipasi dan hasil belajar pada pelajaran yang bersifat teoritis dan hitungan khususnya dalam kompetensi dasar mendeskripsikan Fungsi Pajak dalam Perekonomian Nasional. 3) Dalam pelaksanaan model pembelajaran ini diharapkan guru melengkapinya dengan pemanfaatan media yang menarik bagi siswa serta menyesuaikan dengan kondisi kelas yang dihadapi.

\section{DAFTAR PUSTAKA}

10.22202/economica.2015.v4.i1.309

Achmat, Zakarija. 2005. Hubungan antara Tingkat Partisipasi dengan Hasil Belajar Peserta Pelatihan Pengembangan Kepribadian dan Kepemimpinan Mahasiswa Baru UUM Tahun 2005/2006. Universitas Muhammadiyah

Malang.Publikasi.umm.ac.id/.../jiptumm dppm-gdl-zakarijaac-93-1-hubungandoc. Diakses 21 Desember 2009

Arikunto, Suharsimi. 1993. Manajemen Pengajaran Secara Manusiawi. Jakarta: Rineka Cipta

.2006. Penelitian

Tindakan

Kelas. Jakarta: Bumi Aksara

Badudu. 1994. Kamus Besar Bahasa Indonesia. Pustaka Sinar Harapan baru 
Dalyono. 2005. Psikologi pendidikan. Jakarta: Rineka cipta.

Dimyati dan Mudjiono. 2006. Belajar dan Pembelajaran. Jakarta: Rineka Cipta

Djaafar, Tengku Zahara. 2001. Kontribusi Strategi Pembelajaran Terhadap Hasil Belajar. UNP

Hamalik, Oemar. 2008. Proses Belajar Mengajar. Jakarta: Bumi Aksara

Hasibuan. 2002. Proses Belajar Mengajar. Bandung: PT Remaja Rosdakarya

Irianto, Agus. 2007. Stastistik-Konsep Dasar dan Aplikasinya. Jakarta: Kencana

Kunandar. 2008. Langkah Mudah Penelitian Tindakan Kelas Sebagai Pengembangan Profesi Guru. Jakarta: Rajagrafindo Persada

Nasution. 2008. Berbagai Pendekatan Dalam Proses Belajar Mengajar. Jakarta: Bumi Aksara

Prawiradilaga, Dewi Salma. 2008.Prinsip Disain Pembelajaran.Jakarta : Kencana

Sagala, Syaiful. 2003. Konsep dan Makna Pembelajaran. Bandung: Alfabeta

Sastropoetra, Santoso. 1992. Partisipasi dan Disiplin Dalam Pembangunan Nasional. Bandung: Alumni

Slameto. 2003. Belajar dan Faktor-Faktor yang Mempengaruhinya. Jakarta: Rineka Cipta

Sopah, Djamaah. 1998. "Pengaruh Model Pembelajaran ARIAS dan Motivasi Berprestasi Terhadap Hasil Belajar Siswa". www. Depdikbud.or.id. (dikutip tanggal 13 April 2009) Jakarta: PPS-IKIP Jakarta.

Sudjana, Nana. 1991. Penilain Hasil Belajar. Jakarta: Rineka Cipta

Sugiyono. 2009. Statistika untuk Penelitian. Bandung: Alfabeta
Sukardi. 2008. Metodologi Penelitian Pendidikan. Jakarta: Bumi Aksara

Uno, Hamzah. 2008. Model Pembelajaran. Jakarta : Bumi Aksara

Wardhani, Igag. Dkk.2007. Penelitian Tindakan Kelas. Jakarta : PT. Grafindo Persada 